\title{
The Use of Project Based Learning in Teaching French
}

\author{
Farahdiba \\ Department of Educational Technology Postgraduate \\ Program \\ Medan, Indonesia \\ Email: farahdibamanurung@yahoo.com
}

\author{
Abdul Hasan Saragih, Naeklan Simbolon \\ Department of Educational Technology Postgraduate \\ Program \\ Medan, Indonesia
}

\begin{abstract}
The aim of this research is for knowing the effect of learning model and learning motivation on French's learning outcomes. The learning models used in this research are Project Based Learning and Contextual Teaching and Learning. The research method was quasi-experimental study using factorial $2 \mathrm{x}$ 2 designs. The population consisted of 280 students in the 11th grade student in High School 21 Medan in the second semester 2018/2019 academic years and the sample consisted of 66 students. The technique of data analysis used is ANOVA two ways. The conclusion of the research shows that: there is difference between students French's learning outcomes which is taught using Project Based Learning with Contextual Teaching and Learning. The learning outcomes of French taught by using Project Based Learning is higher than the learning outcomes of French taught by using Contextual Teaching and Learning, there is a difference between students French learning outcomes who are high and low motivation, that there is interaction between learning model and learning motivation to French learning results.
\end{abstract}

Keywords: Learning Models, Project Based Learning, Contextual Teaching and Learning, Learning Motivation.

\section{INTRODUCTION}

French is currently developing rapidly in French- speaking countries / Francophone Countries such as Switzerland, Belgium, Luxembourg, Morocco, Canada, Vietnam, and other countries as well as in non-French- speaking countries, such as Indonesia, Malaysia, Singapore, Thailand and other ASEAN countries [1]. French is the second international language besides English which is widely studied in schools, universities and even used in foreign domestic companies such as in tourism, hospitality, translation and international relations. In fact, French has also become one of the languages that must be studied in several high schools and has been included in the chosen subject of senior high schools in the 2013 curriculum which has been ongoing since 2013 until now.

In Medan, one of the high schools that have been implementing French for a long time is high schools 21 Medan. French learning is not only learning language related to grammar, reading or writing procedures, but must reflect the competence of polite language attitude, scientific.

thinking, and communicative language skills both oral and written, both active and passive through listening skills speaking, reading and writing. French subjects where learning is based on themes, meaning learning through themes used to understand the structure of the text, linguistic elements and cultural elements contained in the text [2].

In learning French, students must also have and master four language skills that are interrelated with one another. According to [3], language skills (language arts, language skills) in the curriculum at school usually includes four aspects, namely listening / listening skills, listening skills, speaking skills, reading skills, and writing skills. These skills will be learned by students in class and are expected to be able to master the four language skills.

Of the four language skills above, the very weak skills to be learned and mastered by students in the school are speaking skills. Speaking skills are very important to be trained and developed so students can communicate well, not just focus on writing skills by only prioritizing sentence

Of text structure in learning French in writing. One aspect of language that must be mastered by students is speaking because speaking skills support other skills (listening, reading comprehension, and writing. Students who have good speaking skills will speak easily to listeners.

Supriyadi (2005) said that if someone has good speaking skills, he will gain social benefits (social interaction activities of individuals) and professional benefits (use of language to make questions, convey facts and knowledge, explain and describe). So, this speaking skill can make it easier for students to communicate and express ideas or opinions to others [4].

Weak speaking skills of students at the school can be seen from student learning outcomes. Based on observations at high school 21 Medan, it turns out there are still many students who get grades below the KKM (Minimum Mastery Criteria) in speaking skills seen from the results of learning French in speaking skills of class XI students in the last 3 years from the academic year 2015/2016 to 2017 / 2018.

Based on the results of interviews with French language teachers at the school, there are several obstacles in learning French, first, students are still difficult to speak in French due to the lack of students' ability to remember and master French vocabulary where the language has written and spoken different. According to [5] the main problem in learning in formal education (schools) today is the low absorption of students. So, if students have low absorption capacity in learning, it will be difficult to remember and master French vocabulary and students are not able to speak French. 
Therefore, mastery of vocabulary is very important in learning French.

According to [6], in mastering vocabulary has a very important role because a person's mind will only be well understood by other parties if the idea can be expressed with the chosen vocabulary correctly because vocabulary is an important vehicle in communication. If there is not enough vocabulary, communication will be hampered. Second, the lack of motivation to learn French so that students never or rarely repeat the pronunciation and writing of French words or sentences that have been taught by the teacher in class.

Based on observations also in one of the classes at the school, there are several obstacles in the learning process of French, namely first, the teacher still uses conventional methods or lecture methods to explain learning material and assignments / exercises in student books / worksheets (LKS) which only focused on grammar and sentence structure in writing skills only during the learning process so that French learning outcomes are still low in speaking skills. According to, based on the results of a research analysis of the learning outcomes of students due to the dominance of conventional learning processes. In this learning, class atmosphere tends to be teacher-centered, so students become passive. Even so the teacher prefers to apply the model, because it does not require tools and practical materials, it is sufficient to explain the concepts in the textbook or other references.

Second, the lack of motivating students in learning French, both in terms of the benefits of learning French, French culture, the benefits of continuing education in France, and all things about French and its language that can attract students' attention to learn French. Third, the lack of demonstrating pronunciation of French vocabulary such as rarely using French language instruction in teaching and rarely listening or giving training through video conversations, films or songs in French due to lack of school facilities such as in focus to facilitate teachers in explaining subject matter so that students still unfamiliar in mentioning words or sentences like native speakers.

Fourth, the lack of interaction between the teacher and students so that the learning process does not attract students' motivation to learn. Fifth, the lack of assigning speaking skills and only giving written assignments. Sixth, the lack of concentration of student learning when studying during the daytime or the last hour of study because previously they have learned several subjects and the teacher does not use learning models that can attract students' attention to learn during the day.

Based on the results of interviews and observations in class, that there are obstacles or problems that have been found in learning French, namely the problem of teaching French teachers and the constraints of students in learning French. In this case, increasing the success of teacher teaching and student learning in class is very important so that student learning outcomes can be improved.

One learning model that can be used in learning French is the Project Based Learning. According, Project Based Learning is the application of active learning. Simply stated, Project Based Learning is defined as a teaching that tries to link technology with everyday life problems that are familiar with students, or with school projects. This Project Based
Learning has enormous potential to make learning experiences more interesting and useful for students.

The characteristics of project-based learning according to [7] are (1) students make their own decisions within a framework that has been previously determined together, (2) students try to solve a problem or challenge that does not have a definite answer, (3 ) students are encouraged to think critically, solve problems, collaborate, and try various forms of communication, (4) students are responsible for finding and managing their own information, (5) evaluations are carried out continuously throughout the project, and (6) students regularly reflect and reflect on what they have done, both the process and the results.

So, this Project-Based Learning when viewed from the process or its characteristics, if applied in French learning can improve student activity in learning or solve French learning problems with critical thinking both individually and in groups by linking learning material with daily life. Days to be more interesting and useful for learning French in class

\section{REVIEW OF THE LITERATURE}

\section{A. Description of Project Based Learning}

According to [8], "Project-based learning is typically considered an approach to teaching in which students respond to real world questions or challenges through an extended inquiry process."

According to [9], "Project-based learning organizes learning around project and involves the students in authentics situations where they can explore apply the subject matter to problems that are complex and relevant to the professional practice for which they are preparing."

According to [10], "The caracteristics of project-based learning are developing students thinking skill, allowing them to have creativity, encouraging them to access the information on their own and to demonstrate this information.".

According to [11], Project Based Learning is a learning process that involves a project in the learning process. Projects undertaken by students can take the form of individual or group projects and are carried out within a certain period of time collaboratively, producing a product, the results of which will then be displayed or presented. Project implementation is carried out in a collaborative and innovative, unique way, which focuses on solving problems related to student life.

Similar to the opinion of, which states that Project-Based Learning as a learning model that provides opportunities for teachers to manage learning in the classroom by involving project work. Project work is a form of work that contains complex tasks based on questions and problems that are very challenging and require students to design, solve problems, make decisions, conduct investigative activities, and provide opportunities for students to work independently.

From some of the opinions above, it can be concluded that the Project Based Learning Model is a teaching approach that gives teachers the opportunity to manage learning in the classroom by involving students in working on an individual or group project that is carried out within a certain period in a collaborative, innovative and unique, the results of which will then be displayed or presented.

In this learning model, students are required to be able to explore learning resources or access information on their own, 
develop students' thinking and creativity skills, design, solve problems, make decisions and conduct investigative activities in solving complex and relevant problems in a project.

The steps of Project-Based Learning in as developed by The George Lucas Educational Foundation translated in detail by Al-Tabany are: (1) Start with the essenstial question, (2) Design a plan for the project, (3) Create a schedule, (4) Monitor the student of the progress project, (5) Assess the Outcome, and (6) Evaluate the experience.

\section{B. Description of Learning Motivation}

According to [12] motivation is a change of energy in a person that is characterized by the emergence of affective (feelings) and reactions to achieve goals. Thus the emergence of motivation is marked by a change in energy in a person that can be realized or not. According to [13], learning motivation is the tendency of students to carry out a learning activity that is driven by a desire to achieve the best achievement or learning outcomes. Motivation is seen as a mental impulse that moves and directs human behavior, including learning behavior. In motivation contained the desire to activate, move, channel and direct attitudes and behaviors in individual learning [14]).

From some of the above understanding it can be concluded that learning motivation is a change in the energy of a person, individual/student who is driven by a desire or feeling and reaction to achieve a goal that is in achieving learning goals such as good achievement or learning outcomes where the encouragement can move, channel and directing the individual or student to study.

There are several things that must be considered by the teacher to motivate students as stated by [15], are: Clarify the objectives to be achieved, Generating student interest, Creating a pleasant atmosphere for learning, Give reasonable praise for each student's success, Give an assessment, Make comments on the results of student work, and Create competition and cooperation.

According to [16], someone who has high learning motivation has the following characteristics:

1) Persevering in the task (can work continuously for a long time, never stop before completion), 2) Resilient face difficulties (not quickly despair). Does not require encouragement from the outside to achieve the best possible (not quickly satisfied with the achievements he has achieved), 3) Showing interest in various problems for adults (development, religion, politics, economics, justice, etc., 4) Prefer to work independently, 5) Get bored quickly with routine tasks (things that are mechanical, just repetitive so less creative), 6) Can defend his opinion (if you are sure of something), 7) It is not easy to let go of the thing believed, and 8) Happy to find and solve problems

\section{METHOD}

This research was conducted in a public high school, named SMA Negeri 21 Medan at Jalan Keramat Indah/Selambo Ujung, Kel. Medan Tenggara, Kec. Medan Denai in class second grade in the academic year 2018/2019. The population in this study is all students of class second grade SMA Negeri 21 Medan consisted of 4 sciences classes and 4 social classes year 2018/2019 classes of classes second grade. The sampling technique in this research is by cluster random sampling technique, social class second grade 3 amounted to 33 students of the class given the learning with Project Based Learning and social class second grade 1 amounted to 66 students of the class given the learning with Contextual Teaching and Learning at SMA Negeri 21 Medan. The method used in this research is the experimental method (quasi experiment). The research design used is the factorial design $2 \times 2$, which compares the Project Based Learning and the Contextual Teaching and Learning to higher learning motivation and the lower ones.

Table 3.1 Design of Student Learning

\begin{tabular}{|c|c|c|}
\hline Class & Treatment & Post-Test \\
\hline Experiment & $\mathrm{X}$ & $\mathrm{T}_{1}$ \\
\hline Experiment & $\mathrm{Y}$ & $\mathrm{T}_{2}$ \\
\hline
\end{tabular}

Information:

$\mathrm{X}=$ Treatment in the experimental class is the application of Project Based Learning

$\mathrm{Y}=$ Treatment in the control class is the application of the Contextual Teaching and Learning.

$\mathrm{T} 1=$ Post-test in the two experimental class and after Treatment

To observe learning motivation that is after students are grouped based on the test. The research design used is factorial designs $2 \times 2$, which compares Project Based Learning and Contextual Teaching and Learning with higher and lower learning motivation. The instrument in this study was to use a test of students' ability to speak French to measure learning outcomes, questionnaires to detect the learning motivation. Hypothesis testing using two-way variance analysis technique $(2 \times 2$ factorial design $)$ with a significant level of $5 \%$.

\section{RESULTS}

From the results of data analysis, researcher obtained the following data, such as : Normality test is done to determine whether the data is normally distributed or not. This study used chi-square table. Based on the calculation result, researcher obtained $\chi 2$ count for Project Based Learning is

0.084 while for Contextual Teaching and Learning is 0.016 . For $\chi 2$ table is 0.154 . Based on that result, researcher conclude that $\chi 2$ count $<\chi 2$ table and data is normally distributed. Homogeneity test was conducted to obtain the assumption that the study sample were from the same condition. Homogeneity test was also conducted to find out whether both data had the same sample variance. Based on the calculation result, researcher obtained Fcount is 2.11 while Ftable is 7.8. Based on that result, researcher conclude that Fcount < Ftable and data is homogeneous. The hypothesis formulated in this study is the students learning outcomes by using Project Based Learning and Contextual Teaching and Learning.

To know whether the students' learning outcomes by using Project Based Learning is better than the students the Contextual Teaching and Learning, researcher conducted calculation by using $\mathrm{T}$ test and the criteria are : Fcount < 
Ftable, then $\mathrm{H} 0$ accepted and $\mathrm{H} 1$ rejected. Fcount > Ftable, then $\mathrm{H} 0$ rejected and $\mathrm{H} 1$ accepted. Based on the calculation that used $\mathrm{T}$ test, researcher obtained Fcount is 4.79 while Ftable is 3,99. Researcher conclude the students who are taught by using Project Based Learning is better than the students who are taught by using Contextual Teaching and Learning.

Thus, the proposed research hypothesis that there is interaction between learning model and learning motivation to French learning results. When viewed from the average in groups of students who have high learning motivation and are taught with a Project Based Learning is higher than the average learning outcomes of other student groups. This is because learners can follow the learning well, where learners are able to express their opinion, discuss in a teamwork, and learning by playing the role. Meanwhile, in teaching and learning activities, either in a Project Based Learning or Contextual Teaching and Learning can take place interactively because the atmosphere of learning is fun. Learning using the Project Based Learning of teachers is no learning center but centered on the students

themselves. That is intended to provide an understanding to learners in knowing, understanding the various materials using this model, that information can come from anywhere, anytime, regardless of teacher's inline information. The essence of this approach expects students to observe, question, reason, try, communicate (create networks) of everything related to the learning process itself. Through this approach students are expected to speak, write and can learn and work in groups.

\section{CONCLUSION}

The results showed that the outcomes of the students who are taught by Project Based Learning are higher than the students who are taught by the Contextual Teaching and Learning. There is an interaction between learning models and learning motivation for the students' learning outcomes. There is a difference in the ability with higher learning motivation, and, there is no significant difference on the students' who had the low learning motivation.

\section{References}

[1] Rahayu, S.P. \& Alice A. (2010). Mille Chemins Créatifs Pour Enseigner Le Français. Yogyakarta : Universitas Negeri Yogyakarta.

[2] Kemendikbud. (2014). Pembelajaran Bahasa Prancis. Jakarta : Kemendikbud.

[3] Tarigan, H.G. (2005). Berbicara Sebagai Suatu Keterampilan Berbahasa. Bandung : Angkasa.

[4] Supriyadi, dkk. (2005). Pendidikan Bahasa Indonesia 2. Jakarta : Depdikbud.

[5] Al-Tabany, T.I.B. (2014). Mendesain Model Pembelajaran Inovatif, Progresif, dan Kontekstual. Jakarta : Prenadamedia Group.

[6] Bédard, D.C., et al. (2012). Problem-based and project-based learning in engineering and medicine: Determinants of students'engagement and persistence. Interdiciplinary Journal of Problem-Based Learning. 6(2). 730.

[7] Hamdu. (2011). Pengaruh Motivasi Belajar Siswa Terhadap Prestasi Belajar IPA di Sekolah Dasar. Jurnal Penelitian Pendidikan. 12(2). 9096.

[8] Hârtescu, I. (2014). Providing technology support to project-based learning. Proc. the International Scientific Conference e-Learning and Software for Education. 3(1). 223-229.

[9] Hosnan, M. (2014). Pendekatan Saintifik dan Kontekstual dalam Pembelajaran Abad 21. Bogor : Ghalia Indonesia.

[10] Kompri. (2016). Motivasi Pembelajaran Perspektif Guru dan Siswa. Bandung : PT. Rosda Karya.

[11] Lattimer. H \& Riordan R. (2011). Project-based learning engages students in meaningful work. Middle School Journal. 43(2). 18-23.

[12] Rusman. (2014). Model-Model Pembelajaran Mengembangkan Profesionalisme Guru (Edisi Kedua). Jakarta : PT. Raja Grafindo Persada.

[13] Nashar. (2004). Peranan Motivasi dan Kemampuan Awal dalam Kegiatan Pembelajaran. Jakarta : Delia Press

[14] Sanjaya, W. (2010). Kurikulum dan Pembelajaran, Teori dan Praktiek Pengembangan Kurikulum KTSP. Jakarta : Kencana.

[15] Syamsuddin \& Damaianti, V.S. (2006). Metode Penelitian Pendidikan Bahasa. Bandung : PT. Remaja Rosdakarya.

[16] Sardiman. (2011). Interaksi dan Motivasi Belajar Mengajar. Jakarta : Rajawali Press 